\title{
Intracorneal and Intraocular Invasion of Ocular Surface Squamous Neoplasia after Intraocular Surgery: Report of Two Cases and Review of the Literature
}

\author{
Juan C. Murillo ${ }^{a}$ Anat Galor ${ }^{a} \quad$ Michael C. Wu ${ }^{d}$ Natasha K. Kye ${ }^{e}$ James Wong ${ }^{a}$ \\ Ibrahim O. Ahmed ${ }^{\mathrm{a}}$ Madhura Joag ${ }^{\mathrm{a}}$ Nabeel Shalabi $^{\mathrm{a}}$ William Lahners $^{\mathrm{c}}$ \\ Sander Dubovy a, b Carol L. Karp ${ }^{a}$ \\ a Department of Ophthalmology and ' Florida Lions Ocular Pathology Laboratory, Bascom Palmer Eye Institute, \\ University of Miami Miller School of Medicine, Miami, Fla., and ${ }^{\mathrm{C} C e n t e r ~ f o r ~ S i g h t, ~ S a r a s o t a, ~ F l a ., ~}{ }^{\mathrm{d}}$ Department of \\ Ophthalmology at Group Health Cooperative, Seattle, Wash., and e Davis Eye Center, University of California, \\ Sacramento, Calif., USA
}

\section{Key Words}

Cornea $\cdot$ Tumor $\cdot$ Conjunctiva $\cdot$ Ocular surface squamous neoplasia $\cdot$ Intraocular extension

\begin{abstract}
Purpose: The aim of this paper was to describe 2 cases of ocular surface squamous neoplasia (OSSN) of the conjunctiva with intracorneal and intraocular extension following intraocular surgery. Methods: We conducted a clinical pathological retrospective case series. Results: Case 1 underwent cataract surgery in the setting of an unnoticed adjacent OSSN. An excisional biopsy with cryotherapy and intraoperative mitomycin $C$ was subsequently performed, confirming OSSN. The patient had two recurrences treated topically with resolution. While the conjunctiva remained clear, a corneal haze emanating from the cataract incision site was noted. Penetrating keratoplasty (PK) for this haze revealed midstromal infiltrative carcinoma. Case 2 had a history of herpes simplex keratitis that ultimately required corneal grafts. Fifteen years later, he developed an OSSN treated with exci-
\end{abstract}

sional biopsy and had clear margins. Eight months later, he presented with a recurrence of his OSSN and was treated briefly with topical interferon for 4 weeks; however, he developed an infectious keratitis with a corneal perforation requiring another PK. Four months after PK, low-grade inflammation was noted. Cytology of the anterior chamber aspirate revealed neoplastic squamous cells. Another PK was then performed. Pathology confirmed extensive intraocular neoplasia. Limited exenteration was performed. Conclusion: Patients with a history of OSSN may be at increased risk of neoplastic intraocular extension following intraocular surgery.

(c) 2016 S. Karger AG, Basel

\section{Introduction}

Ocular surface squamous neoplasia (OSSN) encompasses a broad spectrum of neoplastic squamous epithelial abnormalities including squamous dysplasia, squamous cell carcinoma (SCC) in situ, and invasive SCC of

\section{KARGER}

(c) 2016 S. Karger AG, Basel

E-Mail karger@karger.com

www.karger.com/oop
Carol L. Karp, MD

Department of Ophthalmology, Bascom Palmer Eye Institute, University of Miami Miller School of Medicine, 900 NW 17th Street

Miami, FL 33126 (USA)

E-Mail ckarp@med.miami.edu 
the cornea and/or conjunctiva $[1,2]$. OSSN lesions usually arise within the interpalbebral fissure, mostly at the limbus, although they may be found in any part of the conjunctiva and cornea [3]. With a reported incidence rate from 0.13 to 1.9 per 100,000 persons [3], OSSN is the most common nonpigmented tumor of the ocular surface [2].

The rarity of this condition in North America and its higher incidence in African countries and Australia may be proof of the important role of environmental ultraviolet light exposure as a risk factor. In addition, immunosuppression secondary to human immunodeficiency virus (HIV) was strongly associated with an apparent increase in incidence of this disease in Uganda and Malawi [4-6].

Surgical excision with wide surgical margins has been the traditional therapy for OSSN, often with adjunctive cryotherapy [7]. Topical chemotherapeutic agents such as mitomycin-C (MMC) [8], 5-fluorouracil (5-FU) [9], and interferon alpha-2b [10] have also been found to be effective in the management of OSSN.

Though OSSN is considered slow growing and usually follows a benign course, it has the ability to invade the eye and the orbit, or even rarely metastasize. In a population of 150 OSSN cases excised at the Wills Eye Hospital, 5 patients developed recurrent disease with intraocular invasion, all of whom were originally diagnosed with invasive SCC of the conjunctiva [11]. In other large OSSN case series of 389 [12] and 288 [13] patients, however, no intraocular invasion was reported (57 and 62 SCC cases, respectively).

There is a theoretical concern that intraocular extension can occur, if a surgical procedure is performed with an existing ocular surface tumor. However, there are few reports in the literature discussing this entity as a risk factor for a more aggressive disease course. In this report, we describe 2 unusual cases of invasive OSSN that occurred after intraocular surgery and also review the literature with respect to this uncommon manifestation of OSSN.

\section{Methods}

The design was retrospective. The medical records of 2 patients who presented with invasive OSSN into the corneal stroma $(n=1)$ and anterior chamber $(\mathrm{n}=1)$ were reviewed. Patient records were reviewed for demographic information, co-morbidities, OSSN characteristics, and pathologic grading. Treatment information and outcomes were reviewed.

Intracorneal and Intraocular Invasion of OSSN after Intraocular Surgery

\section{Patients and Results}

\section{Case 1}

An 86-year-old male with a past medical history of tobacco abuse and skin, renal, and lung cancer (nonsmall cell carcinoma, T4, N0), underwent uncomplicated temporal clear cornea cataract surgery in his right eye in 2009. Three months following surgery, a temporal limbal lesion of the conjunctiva was noted [American Joint Committee of Cancer (AJCC) clinical T2, NX, M0], and the tumor was excised with cryotherapy, MMC, and amniotic membrane reconstruction. Pathologic analysis revealed conjunctival carcinoma in situ with clear surgical margins. One year later, the patient developed a recurrent OSSN (AJCC clinical T1 NX, M0; fig. 1a), which was treated with 4 cycles of topical 5 -fluorouracil $1 \%$ with clinical resolution. One year later, he developed another conjunctival lesion in a different location (AJCC clinical T1 NX, M0), which was treated with MMC $0.04 \%$ for 3 cycles. His visual acuity was $20 / 25$, and the conjunctiva and cornea were normal as reported by the treating physician.

In 2013, 4 years after the cataract surgery, the patient presented with a progressive decrease in visual acuity in the right eye. Corneal haze emanating from the temporal cataract incision site was noted (fig. 1b). The limbus and epithelium had a normal appearance (AJCC clinical $\mathrm{T} 3, \mathrm{NX}, \mathrm{M} 0$ ). The patient was not receiving any chemotherapy for his systemic malignancies, and penetrating keratoplasty (PK) was performed (fig. 1c). Histopathological analysis revealed midstromal infiltrative carcinoma with a normal corneal epithelium. There was microscopic extension of the resected tumor to corneal margin (fig. 1d, e). Corneal microbiological studies were negative.

The patient was referred to our service for evaluation. Slit-lamp examination revealed a clear donor cornea. Stromal haze in the recipient was noted at 5-7 o'clock with normal overlying epithelium. Due to the multiple serious health issues, the patient declined any further intervention. At 12 months following the PK, he was noted to have a recurrence of a midstromal haze in the donor tissue (AJCC clinical T3, NX, M0; fig. 1f). The patient declined surgical intervention but agreed to start topical interferon alpha $2 \mathrm{~b} 1 \mathrm{mIU} / \mathrm{ml}$ four times daily. After 2 months of topical chemotherapy, clinical improvement was noted. However, anterior segment high-resolution optical coherence tomography revealed persistent intrastromal disease (fig. 2). The patient died of cardiorespiratory failure secondary to lung cancer 1 month later.

Ocul Oncol Pathol 2017;3:66-72

DOI: $10.1159 / 000450752$ 

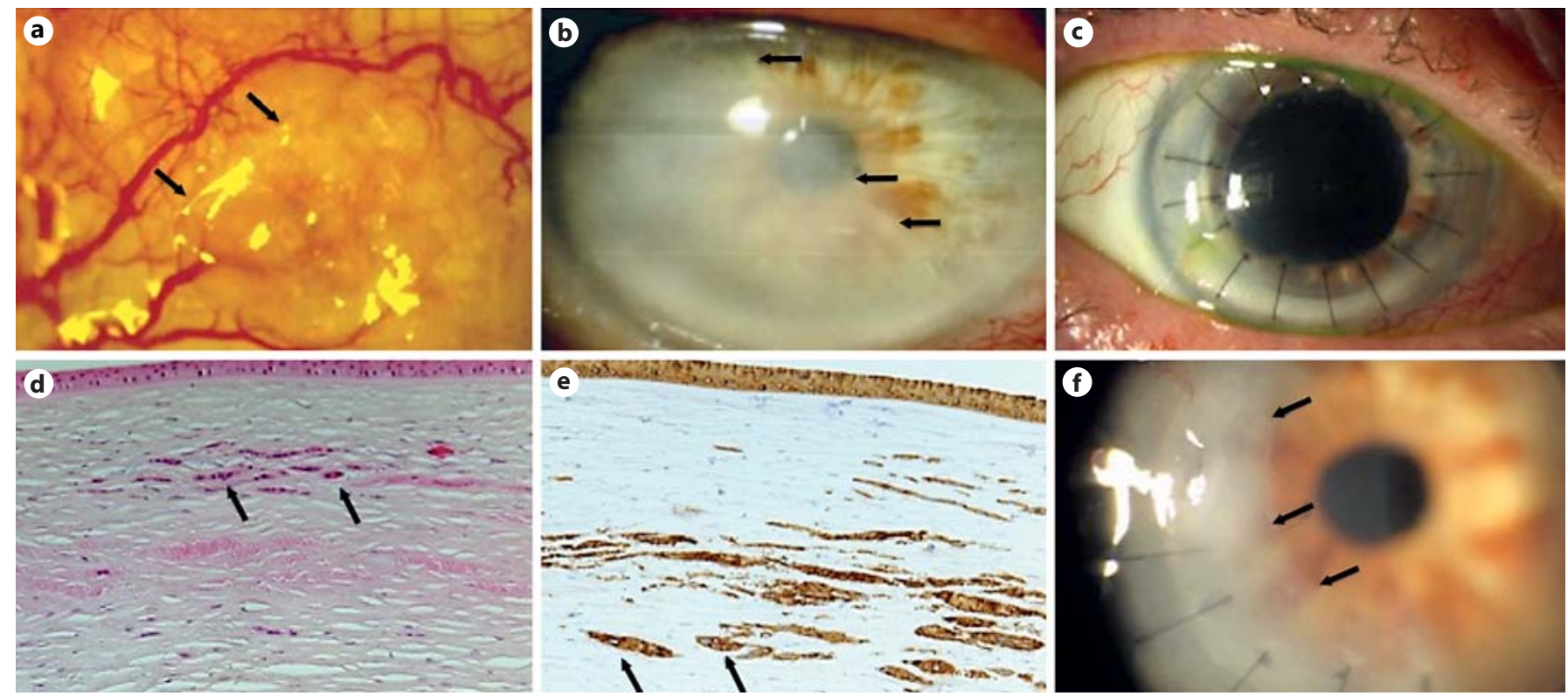

Fig. 1. Case 1. a Slit-lamp photograph of OSSN recurrence demonstrating a conjunctival lesion at 9 o'clock, with a mildly elevated, gelatinous appearance and feeder vessels (arrows). b Slit-lamp photograph of the cornea demonstrating corneal haze originating from the cataract incision site that has crossed into the visual axis (arrows). c Slit-lamp photograph of a clear corneal graft after PK (postoperative day 63). d, e Histopathology of the corneal button

shown in $\mathbf{b}$, demonstrating midstromal infiltrative carcinoma with a normal overlying epithelium. Atypical cells that contain prominent nucleoli are present within the corneal stroma (black arrows) and stain positive for cytokeratin A1-A3 [HE. magnification $\times 200$ (d); cytokeratin A1-A3, magnification $\times 200$ (e)]. f Slit-lamp photograph of the corneal graft with recurrence of the midstromal haze (arrows) 1 year after grafting.

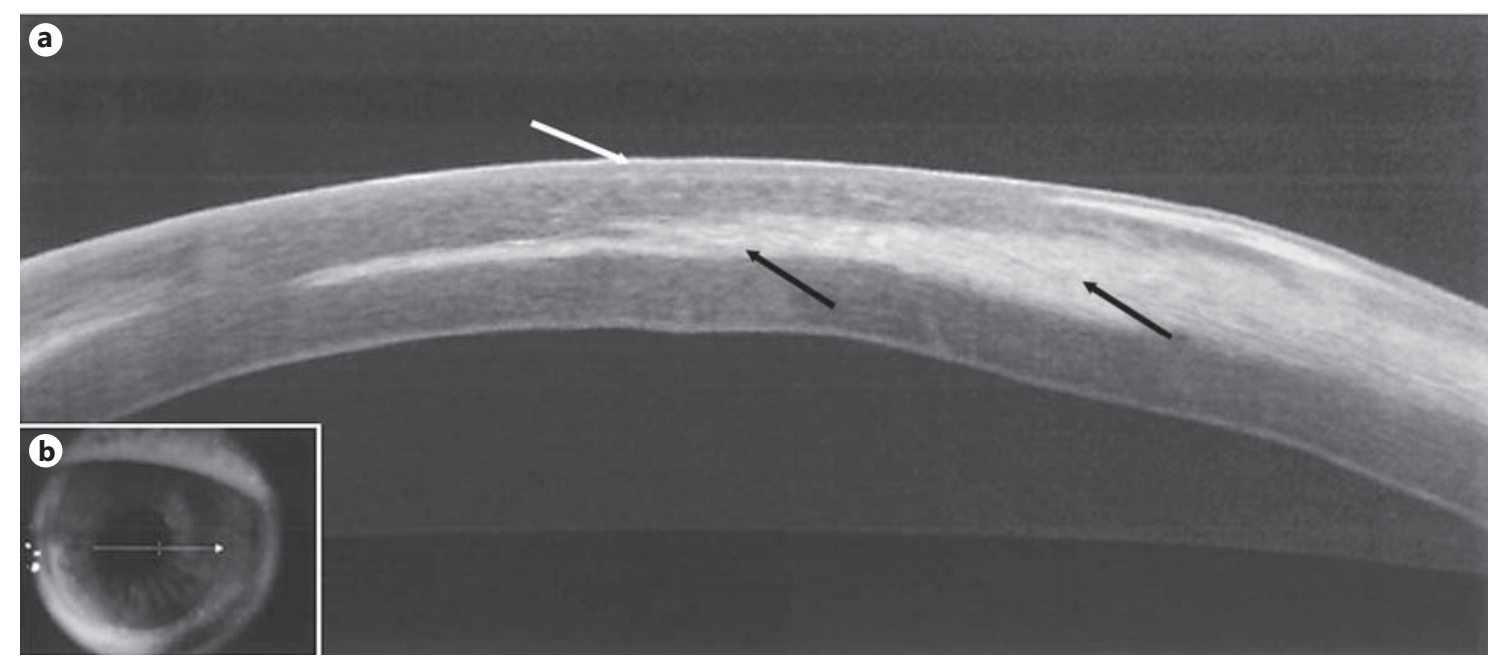

Fig. 2. Case 1. a Anterior segment high-resolution optical coherence tomography of the transplanted cornea reveals recurrence of the midstromal infiltrate (black arrows) within the donor graft with a normal overlying epithelium (white arrow). b Location of the high-resolution optical coherence tomography scan performed. 

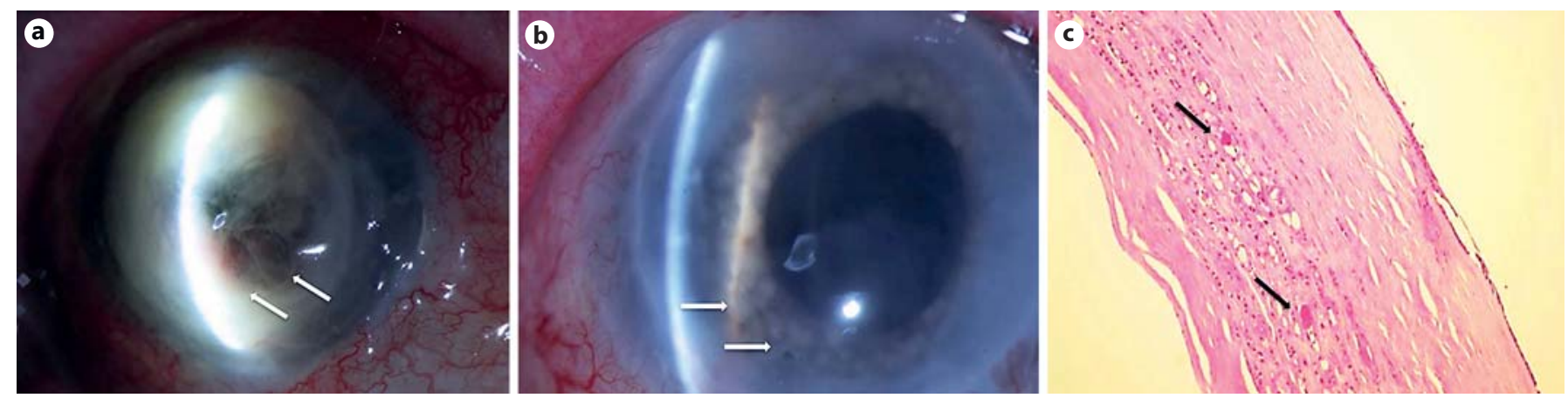

Fig. 3. Case 2. a Slit-lamp photograph of the right eye revealing necrosis and descemetocele in a corneal graft (arrows). b Slit-lamp examination of the patient's iris after diagnostic laser photocoagulation. Blanching of the iris reveals epithelial downgrowth involving the entirety of the iris (arrows). c Histopathology of the corneal button showing keratin nests of neoplastic epithelialization (arrows). HE. magnification $\times 10$.

\section{Case 2}

A 76-year-old white male with a past history of significant solar exposure and two prior PKs for herpes simplex virus (HSV) keratitis presented with two distinct limbal leukoplakic lesions 15 years after his last PK (AJCC clinical T1, NX, M0). The corneal graft was clear, and no anterior chamber cells were present. Excisional biopsy and superficial keratectomy were performed of both lesions and demonstrated mild corneal and conjunctival intraepithelial neoplasia (CIN) temporally and moderate CIN nasally. Surgical margins were clear for both lesions although one specimen was suboptimal (these findings were confirmed by an experienced pathologist at a tertiary institution). Eight months later, the patient was seen by an outside ophthalmologist and diagnosed with recurrence of OSSN and was started on topical interferon therapy. One month after treatment initiation, the patient returned to our service with a large corneal ulcer with corneal stromal necrosis and a central descemetocele (fig. 3a). The cornea was Seidel negative. Gram stain revealed 3+ gram-positive bacteria, which eventually grew Streptococcus viridans. No obvious tumor was visible on the ocular surface. Twenty-four hours later, the ulcer perforated, and a repeat PK was performed. Histopathology of the excised corneal button revealed suppurative necrosis of the corneal stroma extending down to Descemet's membrane. Additionally, microbiological studies disclosed abundant gram-positive cocci within the corneal stroma.

Four months after the PK surgery, the patient was found to have mild, diffuse corneal opacification, inferior keratic precipitates and $2+$ anterior chamber cells. Corticosteroid topical therapy for presumed graft rejection and oral acyclovir for possible recurrent HSV keratitis were started. Despite this therapy, low-grade anterior chamber cell persisted, necessitating a diagnostic anterior chamber paracentesis. Analysis of the aqueous humor was negative for HSV but revealed atypical squamous cells. Diagnostic iris photocoagulation then confirmed epithelial downgrowth (fig. 3b).

Based on this finding, the patient underwent repeat $\mathrm{PK}$ with pupillary membranectomy and therapeutic iris cryotherapy. Histopathology of the corneal specimen revealed atypical, keratinizing, proliferative squamous cells distributed in an infiltrative pattern throughout the corneal stroma, including deep portions abutting Descemet's membrane; consistent with extensive neoplastic invasion into the anterior segment (fig. 3c). A modified enucleation/limited exenteration (removal of globe with adjacent conjunctiva) was performed as described by Shields et al. [11]. The patient has had no tumor recurrence over a follow-up period of 4.5 years.

\section{Literature Review of OSSN and Intraocular Surgery}

Three previous cases of invasive OSSN following cataract surgery have been reported (table 1). The mean age at the time of OSSN detection was 71 years (range 64-76), and all patients were white. No patients were locally or systemically immunosuppressed. None of the 3 reported patients had a history of OSSN prior to their cataract surgery. The diagnosis of OSSN with intraocular invasion was made on an average of 2.2 months (range 0.7-5) after the surgery [14-16]. In the case reported by Balestrazzi et al. [14], only a pinguecula was noted before cataract surgery. One month after cataract surgery, an ocular surface 
Table 1. Reports of OSSN with intracorneal and intraocular invasion after intraocular surgery

\begin{tabular}{|c|c|c|c|c|c|c|c|c|c|c|}
\hline $\begin{array}{l}\text { First author } \\
\text { [ref.] }\end{array}$ & Year & $\begin{array}{l}\text { Age, } \\
\text { years }\end{array}$ & $\begin{array}{l}\text { Race/ } \\
\text { gender }\end{array}$ & $\begin{array}{l}\text { History OSSN } \\
\text { prior to surgical } \\
\text { procedure }\end{array}$ & $\begin{array}{l}\text { Surgical } \\
\text { procedure }\end{array}$ & $\begin{array}{l}\text { Time surgery } \\
\text { to intraocular } \\
\text { extension }\end{array}$ & $\begin{array}{l}\text { Location } \\
\text { of extension }\end{array}$ & Management & $\begin{array}{l}\text { Histopathology } \\
\text { diagnosis }\end{array}$ & Follow-up \\
\hline $\begin{array}{l}\text { Balestrazzi } \\
{[14]}\end{array}$ & 2008 & 64 & $\begin{array}{l}\text { white } \\
\text { male }\end{array}$ & $\begin{array}{l}\text { no } \\
\text { (pinguecula) }\end{array}$ & CE & 1 month & corneal stroma & topical MMC & $\begin{array}{l}\text { OSSN } \\
\text { (not subtyped) }\end{array}$ & $\begin{array}{l}\text { no } \\
\text { recurrence or } \\
\text { metastasis } \\
\text { ( } 6 \text { months })\end{array}$ \\
\hline $\begin{array}{l}\text { Rootman } \\
{[15]}\end{array}$ & 2012 & 72 & $\begin{array}{l}\text { white } \\
\text { male }\end{array}$ & $\begin{array}{l}\text { no } \\
\text { (pterygium) }\end{array}$ & $\begin{array}{l}\text { pterygium } \\
\text { excision } \\
\text { and } C E\end{array}$ & 0.7 months & $\begin{array}{l}\text { iris, ciliary } \\
\text { body, } \\
\text { suprachoroidal } \\
\text { space }\end{array}$ & enucleation & SCC & not described \\
\hline $\begin{array}{l}\text { Present } \\
\text { report }\end{array}$ & 2016 & 86 & $\begin{array}{l}\text { white } \\
\text { male }\end{array}$ & no & $\mathrm{CE}$ & 36 months & corneal stroma & $\mathrm{PK}$ & $\begin{array}{l}\text { intrastromal } \\
\text { carcinoma }\end{array}$ & $\begin{array}{l}\text { intrastromal } \\
\text { recurrence in } \\
\text { PK } 1 \text { year } \\
\text { after surgery; } \\
\text { no } \\
\text { recurrence or } \\
\text { metastasis } \\
\text { (4 years) }\end{array}$ \\
\hline
\end{tabular}

$\mathrm{CE}=$ Cataract extraction

tumor with leukoplakia and papillary features was noted at the area of the side port incision. Confocal microscopy was used to diagnose intracorneal OSSN. This patient was treated successfully with topical MMC, and the surface and intracorneal findings resolved. In 1 of the cases reported by Rootman et al. [15], combined cataract and presumed pterygium surgery were performed. Unfortunately, the pathology on the presumed pterygium specimen was SCC. Within 3 weeks, intraocular inflammation and an anterior chamber mass were noted. This eye was enucleated, and neoplasia was found diffusely spread intraocularly. Finally, the case by Stone [16], uneventful cataract surgery was performed, and no ocular surface lesions were noted. Five months after the surgery, the patient developed intraocular inflammation and eventually an iris mass. The eye became prephthisical and painful. The eye was enucleated and showed OSSN invading through the cataract incision site inside the eye.

Certain histologic subtypes of SCC, such as the rare mucoepidermoid variant, exhibit an aggressive behavior with a tendency to intraocular invasion and early recurrence when incompletely excised [17-23]. Interestingly, none of the cases described above had mucoepidermoid neoplasia. Their only risk factor for invasion was the concurrent cataract surgery.

\section{Discussion}

OSSN is considered to be a low-grade malignancy, and its behavior is not typically aggressive. Risk factors for the development of disease include environmental ultraviolet light exposure, human papilloma virus, cigarette smoking, immunosuppression, and human HIV [4-6, 24].

Features that portend a poorer prognosis include a prior history of OSSN, xeroderma pigmentosa, late presentation, and a higher malignancy grade (SCC and carcinoma in situ versus CIN) as well as positive pathological margins $[12,25,26]$. Furthermore, HIV has also been associated with a more aggressive behavior: in a case-control study of 200 OSSN cases in India, HIV-positive individuals presented with larger and thicker tumors and showed higher incidence of intraocular invasion [27].

Other reported risk factors for local invasion include mucoepidermoid and spindle variants of carcinoma [1723]. In their review of 5 cases of mucoepidermoid carcinoma of the conjunctiva, Rao and Font [17] found intraocular invasion in 2 cases and orbital extension in 3 cases. None of the cases in our review of postsurgical invasive OSSN with available pathology had mucoepidermoid or spindle variants noted on histopathologic analysis. In our 
review of the literature, 2 cases of the postsurgical OSSN were SCC, but of note, both of our cases had noninvasive, intraepithelial disease as the primary lesion.

Our cases suggest that surgical intervention, which creates a track for tumor cells to enter the eye, may be a risk factor for intraocular OSSN. This may partly be explained by a disruption of Bowman's layer, which is thought to be a barrier for tumor invasion [3].

Two large series of 389 [12] and 288 [13] OSSN patients (57 and 62 of which had SCC, respectively), found no intraocular invasion at presentation or follow-up (up to 13 and 3 years, respectively) after surgical removal of OSSN. This reinforces the concept that unless a track is available or the tumor is a mucoepidermoid variant, intraocular penetration of a tumor is a rare event.

Our cases also demonstrate the varied clinical presentations of invasive intraocular OSSN. In 1 case, the disease manifested as stromal haze without an apparent epithelial abnormality. In another, the intraocular malignancy manifested as a low-grade corticosteroid-resistant iritis.

In conclusion, our cases and the 3 described in the literature illustrate that patients who undergo an intraocular surgical procedure with malignant cells on the surface of the eye may be at increased risk of invasive OSSN. In patients with a history of a surface neoplasia and an intra- ocular surgical procedure, findings of intrastromal corneal haze, and atypical intraocular inflammations or membranes, intraocular neoplasia must be suspected.

\section{Acknowledgments}

This paper was supported by the NIH Center Core Grant P30EY014801, RPB Unrestricted Award and Career Development Awards, Department of Defense (DOD Grant No. W81XWH-09-1-0675), the Ronald and Alicia Lepke Grant, the Lee and Claire Hager Grant, the Jimmy and Gaye Bryan Grant, the Gordon Charitable Foundation, and the Richard Azar Family Grant (institutional grants).

\section{Statement of Ethics}

This study was approved by the Institutional Review Board of the University of Miami, and the methods adhered to the tenets of the Declaration of Helsinki and were compliant with the Health Insurance Portability and Accountability Act.

\section{Disclosure Statement}

The authors have no proprietary or commercial interest in any materials discussed in this article.

\section{References}

1 Shields JA, Shields CL: Premalignant and malignant lesions of the conjunctival epithelium; in Shields JA, Shields CL (eds): Eyelid, Conjunctival, and Orbital Tumor: An Atlas and Textbook. Philadelphia, Lippincott Williams and Wilkins, 2008, pp 286-305.

2 Shields CL, Demirci H, Karatza E, Shields JA: Clinical survey of 1643 melanocytic and nonmelanocytic conjunctival tumors. Ophthalmology 2004;111:1747-1754.

3 Lee GA, Hirst LW: Ocular surface squamous neoplasia. Surv Ophthalmol 1995;39:429450.

4 Waddell KM, Lewallen S, Lucas SB, AtenyiAgaba C, Herrington CS, Liomba G: Carcinoma of the conjunctiva and HIV infection in Uganda and Malawi. Br J Ophthalmology 1996;80:503-508.

5 Lee GA, Hirst LW: Incidence of ocular surface epithelial dysplasia in metropolitan Brisbane: a 10-year survey. Arch Ophthalmol 1992;110: 525-527.

6 Shields CL, Ramasubramanian A, Mellen PL, Shields JA: Conjunctival squamous cell carcinoma arising in immunosuppressed patients (organ transplant, human immunodeficiency virus infection). Ophthalmology 2011;118: 2133-2137.

Intracorneal and Intraocular Invasion of OSSN after Intraocular Surgery
7 Fraunfelder FT, Wingfield D: Therapy of intraepithelial epitheliomas and squamous cell carcinoma of the limbus. Trans Am Ophthalmol Soc 1980;78:290-300.

8 Frucht-Pery J, Sugar J, Baum J, Sutphin JE, Pe'er J, Savir H, Holland EJ, Meisler DM, Foster JA, Folberg R, Rozenman Y: Mitomycin C treatment for conjunctival-corneal intraepithelial neoplasia: a multicenter experience. Ophthalmology 1997;104:2085-2093.

9 Parrozzani R, Lazzarini D, Alemany-Rubio E, Urban F, Midena E: Topical 1\% 5-fluorouracil in ocular surface squamous neoplasia: a longterm safety study. Br J Ophthalmol 2011;95: 355-359.

10 Galor A, Karp CL, Chhabra S, Barnes S, Alfonso EC: Topical interferon alpha $2 \mathrm{~b}$ eyedrops for treatment of ocular surface squamous neoplasia: a dose comparison study. $\mathrm{Br}$ J Ophthalmol 2010;94:551-554.

11 Shields JA, Shields CL, Gunduz K, Eagle RC Jr: The 1998 Pan American Lecture. Intraocular invasion of conjunctival squamous cell carcinoma in five patients. Ophthal Plast Reconstr Surg 1999;15:153-160.
12 Galor A, Karp CL, Oellers P, Kao AA, Abdelaziz A, Feuer W, Dubovy SR: Predictors of ocular surface squamous neoplasia recurrence after excisional surgery. Ophthalmology 2012;119:1974-1981.

13 Lee GA, Hirst LW: Retrospective study of ocular surface neoplasia. Aust NZ J Ophthalmol 1997;25:269-276.

14 Balestrazzi A, Martone G, Pichierri P, Tosi GM, Caporossi A: Corneal invasion of ocular surface squamous neoplasia after clear corneal phacoemulsification: in vivo confocal microscopy analysis. J Cataract Refract Surg 2008;34:1038-1043.

15 Rootman DB, McGowan HD, Yucel YH, Pavlin CJ, Simpson ER: Intraocular extension of conjunctival invasive squamous cell carcinoma after pterygium surgery and cataract extraction. Eye Contact Lens 2012;38:133-136.

16 Stone DU, Char DH, Crawford JB, Margolis TP, Van Gelder RN, Strauss EC: Metaplastic squamous epithelial downgrowth after clear corneal cataract surgery. Am J Ophthalmol 2006;142:695-697.

17 Rao NA, Font RL: Mucoepidermoid carcinoma of the conjunctiva: a clinicopathologic study of five cases. Cancer 1976;38:16991709. 
18 Cohen BH, Green WR, Iliff NT, Taxy JB, Schwab LT, De la Cruz Z: Spindle cell carcinoma of the conjunctiva. Arch Ophthalmol 1980;98:1809-1813.

19 Brownstein S: Mucoepidermoid carcinoma of the conjunctiva with intraocular invasion. Ophthalmology 1981;88:1226-1230.

20 Searl SS, Krigstein HJ, Albert DM, Grove AS Jr: Invasive squamous cell carcinoma with intraocular mucoepidermoid features. Conjunctival carcinoma with intraocular invasion and diphasic morphology. Arch Ophthalmol 1982;100:109-111.
21 Gamel JW, Eiferman RA, Guiba P: Mucoepidermoid carcinoma of the conjunctiva. Arch Ophthalmol 1984;102:730-731.

22 Margo CE, Groden LR: Intraepithelial neoplasia of the conjunctiva with mucoepidermoid differentiation. Am J Ophthalmol 1989; 108:600-601.

23 Carrau RL, Stillman E, Canaan RE: Mucoepidermoid carninoma of the conjunctiva. Ophthal Plast Reconstr Surg 1994;10163-168.

24 Verma V, Shen V, Sieving PC, Chan CC: The role of infectious agents in the etiology of ocular adnexal neoplasia. Surv Ophthalmol 2008;53:312-331.
25 Pe'er J: Ocular surface squamous neoplasia. Ophthalmol Clin N Am 2005; 18:113.

26 Babar TF, Khan MN, Hussain M, Shah SA, Khan MY, Khan MD: Spectrum of ocular surface squamous neoplasia. J Coll Physicians Surg Pak 2007;17:344-346.

27 Saurabh K, Swathi K, Dilip K, Jyoti B, Milind $\mathrm{N}$ : Ocular surface squamous neoplasia in 200 patients: a case-control study of immunosuppression resulting from human immunodeficiency virus versus immunocompetency. Ophthalmology 2015;122:1688-1694. 